\title{
Agritourism operators embrace social media for marketing
}

W hen it comes to marketing, the hottest topic among California's agritourism operators is clearly social media. Many operators are embracing this tool to market their farm-related businesses.

"We're seeing the older generation eager to learn from the 30-year-olds how to jump into this

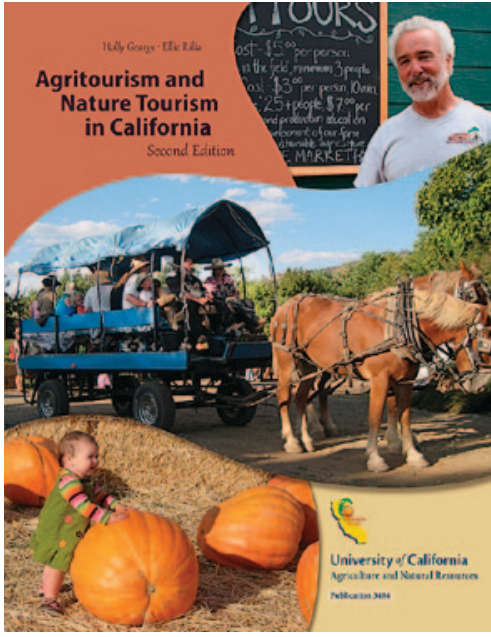

The second edition of Agritourism and published later this year. Nature Tourism in California will be new way of communicating with their customers," said Penny Leff, agritourism coordinator for the UC Small Farm Program. "But they are also worried about having enough time to learn something new while keeping their businesses running."

Attendees at four recent regional agritourism workshops funded by USDA Western SARE (Sustainable Agriculture Research and Education) - expressed considerable interest in learning how to use Facebook, Twitter, blogs, YouTube and other new tools.

"[Social media is] the most affordable, efficient, time-conscious way to interact with people, keep tabs on changing market trends, brand your business and tell your story," said marketer Chris Kerston of Chaffin Family Orchards in Oroville. "Expect it to take a

\section{Hilgardia digitization project under way}

U $C$ faculty and staff are spearheading an effort to scan and digitize Hilgardia, the primary technical publication of UC Agriculture and Natural Resources for 70 years.

Although production ceased in 1995, Hilgardia includes classic editions that formed the cornerstones of agricultural, environmental and nutritional research. The journal is still widely cited in scientific literature.

Despite its distinguished past, Hilgardia has virtually no web presence, and one-half of published issues (including the first 24 volumes and 58 other editions) are now out of print. The remaining paperbound journals are subject to physical degradation.

The committee's goal is to raise $\$ 30,000$ for scanning and digitization. The Hilgardia monographs will then be posted online, freely available to scholarly and lay readers worldwide.

To make a donation or for more information, send e-mail to calag@ucdavis.edu or Deborah Golino atdagolino@ucdavis.edu, or go to: http://californiaagriculture.ucanr.org/hilgardia.cfm. fair amount of time. It might make sense to hire someone."

In response to the key findings from the first statewide agritourism survey (see page 57), the UC Small Farm Program organized the workshops in January and February 2011 to address challenges related to permits, regulations, planning, marketing and risk management. The first four workshops - held in Merced (Merced County), Rio Vista (Solano County), Ukiah (Mendocino County) and Red Bluff (Tehama County) - brought together more than 300 agritourism operators; farmers and ranchers considering agritourism; agricultural and tourism professionals; and regulators, elected officials and community leaders.

"Regulatory issues and tools for marketing agritourism operations were identified as primary concerns," said Ellie Rilla, the study's lead investigator and community development advisor with UC Cooperative Extension in Marin County.

\section{Regulatory approaches}

At the workshops, local planning professionals shared ways that many counties have been incorporating agritourism into their general plan revisions. For example, Calaveras County's latest general plan notes: "The sustainability of the many segments of agriculture in the county is directly related to the success of agritourism and the economic benefits it provides."

Likewise, Butte County's plan states: "By promoting certain aspects of farming as a tourist attraction, agriculturalists educate the public about agricultural land and farming practices, while marketing a variety of retail products."

Butte County is implementing a Unique Agricultural Overlay designation in its general plan in order to protect and promote small-scale agriculture. This designation allows agriculturalsupport and specialty-agriculture uses either by right or under discretionary permit, regardless of whether they are allowed in the underlying zoning. Allowed uses include wineries, roadside stands, farm-based tourism, bed and breakfasts, and ancillary restaurants and stores.

"The designation will be used by small-scale producers in the East Oroville Foothills, the historic center of the Butte County citrus industry from 1900 to 1940," said Butte County principal planner Dan Breedon. "This area includes small-scale citrus, vineyards, orchards, organic gardens, wineries and olive oil tasting, which all can benefit from the county's innovative approach to zoning." - Shermain Hardesty and Editors 